УДК 343.139

DOI https://doi.org/10.15421/3919106

Щербак А. В.,

аспірант кафедри адміністративного та фінансового права

Національного університету біоресурсів і природокористування України

ОСОБЛИВОСТІ РОЗПОДІЛУ СУДОВИХ СПРАВ СЕРЕД СУДДІВ

\title{
PECULIARITIES OF THE DISTRIBUTION OF COURT CASES BETWEEN JUDGES
}

У статті здійснено аналіз правового регулювання відносин, пов'язаних із функціонуванням автоматизованої системи документообігу судів за допомогою інноваційних методів, з метою покращення адміністративних та управлінських функцій у судовій системі країни.

Судова система останніми роками перебуває у центрі уваги багатьох суспільних обговорень. Зміст цих дискусійних питань полягає в ефективності функціонування судових органів. Урахування реального впливу людей - працівників судової системи та учасників судових процесів, на потребу досягнення вимог оптимального розподілу судових справ серед суддів в реальні терміни є гострою необхідністю цієї гілки влади. Відповідно, значним важелем стає використання способів і методів, які дозволять полегшити роботу суду, задовольнити вимоги учасників процесу щодо адміністративної побудови розподілу судових справ і досягнути гарного показника якості судових послуг.

Суди здійснюють судову владу самостійно, незалежно від чиєїсь волі, підкоряючись тільки Конституції України і законодавству України. Якість цієї діяльності, включаючи доступність судової влади, оперативність, розумність і справедливість правосуддя, забезпечують не тільки судді, а й їхні помічники, інші службовці апарату. Створення реальної оптимізації процесів розподілу судових справ $є$ рушійною силою процесу створення ефективної системи у створенні високоякісного оперативного функціонування апарату суду та виправдання довіри до правосуддя.

Розкриття цієї проблеми взято не випадково, оскільки одвічно існує суперечність переваг щодо забезпечення прозорості роботи суду та швидкого і кваліфікованого вирішення справ.

Людські ресурси в системі ефективного судового адміністрування в частині розподілу судових справ серед суддів $є$ значним важелем в удосконаленні цієї системи. Автоматизована система дозволяє зробити цей процес більш інноваційним способом, а людина повинна визначити кращий засіб такого фільтрування, за допомогою якого справи будуть швидко розподілятись, довіра до учасників процесу не буде втрачатись, а рішення будуть виноситись грамотно й оперативно.

Створення позитивного іміджу судової системи за допомогою ефективної роботи суддів через «призму» допоміжних засобів розподілу судових справ є основною ціллю цієї статті.

Ключові слова: автоматизована система, документообіг, адміністрування, апарат, електронні документи.

The article analyzes the legal regulation of the relations related to the functioning of the automated system of court documents circulation by means of innovative methods in order to improve the administrative and administrative functions in the judicial system of the country.

The judicial system has been the focus of much public debate in recent years. The content of these debates lies in the efficiency of the functioning of the judiciary. Considering the real impact of the people of the judiciary and litigants on the need to achieve the optimal distribution of court cases among judges in real time is an urgent need for this branch of government today. Accordingly, the use of methods and methods that will facilitate the work of the court and satisfy the requirements of participants in the process of administrative construction of the distribution of court cases and achieve as a result of a good indicator of the quality of court services is becoming a significant lever.

Courts exercise the judiciary independently, regardless of their will, subject only to the Constitution of Ukraine and the legislation of Ukraine. The quality of this activity, including the accessibility of the judiciary, the promptness, reasonableness and fairness of justice, is ensured not only by the judges, but also by their assistants and other officials of the apparatus. Creating a real optimization of the distribution of court cases is the driving force behind the process of creating an effective system in creating a high-quality operational functioning of the court apparatus and justifying trust in justice.

It is no accident that the disclosure of this problem has been made since there is always a contradiction between the benefits of ensuring the transparency of court work and the swift and qualified resolution of cases.

Human resources in the system of effective judicial administration in terms of the distribution of court cases among judges are significant levers in improving this system. An automated system makes this process a more innovative way, and a person must identify the best means of such filtering, by which, not only will the cases be quickly distributed and confidence from the participants of the process lost, but also a competent and prompt decision is made.

Creating a positive image of the judiciary through the effective work of judges through the "prism" of courtroom auxiliaries is the primary purpose of this article.

Key words: automated system, workflow, administration, apparatus, electronic documents.

Виклики сьогодення щодо необхідності професійно, оперативно і неупереджено здійснювати правосуддя стали фактором необхідності врегулювання проблематики у розподілі судових справ між суддями $з$ додержанням принципів випадковості, в хронологічному порядку надходження судових справ, 3 урахуванням завантаженості кожного судді (збалансованого навантаження).
Для покращення управлінських та адміністративних функцій у контексті розподілу судових справ $\epsilon$ насамперед створення такого способу, що забезпечить реалізацію наданих для судової системи правозастосовчих актів з реальним цільовим втіленням їх цільового призначення.

Правове регулювання відносин, пов'язаних із функціонуванням автоматизованої системи доку- 
ментообігу суду, здійснюється Положенням про автоматизовану систему документообігу суду, у тому числі відповідно до Законів України «Про електронні документи та електронний документообіг», «Про інформацію», «Про доступ до судових рішень», «Про захист інформації в інформаційно-телекомунікаційних системах» та «Про захист персональних даних», «Про електронний цифровий підпис». Положення розроблено відповідно до вимог Закону України «Про судоустрій і статус суддів», Господарського процесуального кодексу України, Кодексу адміністративного судочинства України, Кримінального процесуального кодексу України, Цивільного процесуального кодексу України, Кодексу України про адміністративні правопорушення, Закону України «Про доступ до публічної інформації» та інших нормативних актів [1].

Автоматизований розподіл судових справ здійснюється в автоматизованій системі за такими правилами: із загального списку суддів визначаються судді, які мають повноваження щодо розгляду судової справи на момент автоматизованого розподілу; для суддів, які мають повноваження щодо розгляду судової справи на момент автоматизованого розподілу, здійснюється розрахунок коефіцієнтів навантаження; із числа суддів, які мають повноваження щодо розгляду судової справи на момент автоматизованого розподілу, з урахуванням визначених автоматизованою системою коефіцієнтів навантаження, здійснюється визначення судді для розгляду конкретної судової справи за принципом випадковості. Визначення суддів, які мають повноваження щодо розгляду судової справи на момент автоматизованого розподілу, здійснюється згідно з вимогами Положення про автоматизовану систему документообігу суду, засад використання автоматизованої системи документообігу суду, а також з урахуванням дотримання правил поєднання судових справ. Обрання судді за випадковим числом здійснюється відповідно до коефіцієнту навантаження судді на момент автоматизованого розподілу судової справи. Згідно з умовами Положення також визначаються і повноваження зборів суддів щодо здійснення автоматизованого розподілу судових справ між суддями. Так, збори суддів відповідного суду мають право запроваджувати спеціалізацію суддів 3 розгляду конкретних категорій судових справ. Спеціалізація суддів визначається із розрахунку розподілу не менше двох суддів на одну спеціалізацію. Збори суддів відповідного суду визначають склад колегій суддів суду, мають право визначати коефіцієнт складності категорій судових справ, особливості розподілу судових справ під час виконання суддею інших повноважень, не пов'язаних із здійсненням правосуддя, коефіцієнт адміністративних посад, коефіцієнт, що враховує форму участі судді в розгляді судової справи, тощо [1].

У рамках діяльності проекту Європейського Союзу «Прозорість та ефективність функціонування судової системи України: компонент державної служби» підготовлено видання «Прозорість та ефективність функціонування судової системи України: компонент державної служби» у співпраці з Чорнобаївським районним судом Черкаської області, Первомайським міськрайонним судом Харківської області, Петровським районним судом міста Донецька, Івано-Франківським міським судом, Дніпровським районним судом міста Києва, Малиновським районним судом міста Одеси, апеляційним судом Івано-Франківської області. У виданні детально описані методи, які використовують вищезазначені суди у своїй діяльності з метою покращення адміністрування. Особливу увагу приділено організаційній структурі суду, делегуванню та розподілу повноважень, розподілу справ серед суддів, кадровій роботі, зв'язкам 3 громадськістю та ЗМI, дотриманню правил етичної поведінки, застосуванню інформаційно-комунікаційних технологій. У цьому виданні описуються новітні методи, які було розроблено та запроваджено деякими українськими судами з їх власної ініціативи для покращення своєї роботи. Важливо зазначити, що вони впроваджувалися й продовжують впроваджуватися в умовах постійного браку коштів та надзвичайно обмежених ресурсів [2].

Так, на прикладі Івано-Франківського міського суду розподіл справ здійснюється із застосуванням кількох альтернативних систем розподілу:

Випадковий розподіл - це розподіл апаратними засобами на основі генератора випадкових чисел (або жеребом вручну). Вважаємо цей розподіл найгіршим з усіх можливих, тому що він вимагає більше ресурсів, оскільки всі справи - це кількісні одиниці, які мають однакову вагу. Розрахунки нами приводились, повторювати не будемо. Треба тільки додати, що хаос на вході не зможе породити порядок всередині і на виході. Однак за комбінування його зі спеціалізацією шкода буде меншою.

Почерговий розподіл - це коли з числа суддів за якимось критерієм (алфавіт, вага, зріст) формується черга, і кожна наступна справа передається наступному судді. Так працювати можна, але проблеми ті самі - навантаження запрограмоване нерівномірно.

Розподіл за спеціалізацією - це наш розподіл, тільки 3 продовженням: за спеціалізацією ще й за рівнем складності та призначенням першої зустрічі з суддею. Спеціалізація, як вказувалося, стосується не тільки сфери права, якої стосується справа. Критеріїв може бути багато, і це дуже добре, оскільки можна буде подумати над створенням конструктора організаційного дизайну суду, бо він з самого початку залежить від системи розподілу.

Пропорційний - це розподіл, який може використовувати комбінацію всіх попередніх і навіть випадкового за певних умов. Суть його в тому, що процентне співвідношення справ, які будуть розподілятися, задається, тобто адмініструється. I тоді одному судді, який має гірше становище 3 розглядом справ, будуть розподілятися справи, скажімо, на $10 \%$ менше, ніж іншим. За цим, гадаємо, майбутнє, але зараз організаційні можливості такого розподілу тільки вивчаються [2].

Базовими правовими підставами документообігу в судовій системі є загальні інструкції з діловодства 
в судових інстанціях України; підзаконні акти, які щорічно видає Державна судова адміністрація України; статистична та звітна робота. Важливе прикладне значення мають «Положення про автоматизовану систему документообігу суду», «Інструкція 3 діловодства в місцевих загальних судах та інших...», які редагують і доповнюють відповідно з новими вимогами. На підставі «Положення про автоматизовану роботу суду» створюються «внутрішні» для судів Положення [3].

У ст. 129 Конституції України однією із засад судочинства проголошено гласність судового процесу та його повне фіксування технічними засобами [4]. Створення автоматизованих систем має на меті підвищити якість прийняття рішень за рахунок поєднання того, що є найкращим у людини, тобто в особи, що приймає рішення, та електронно-обчислювальної машини. При цьому доведеним є висновок про те, що на будь-якому етапі технічного розвитку електронний мозок ніколи не зможе повністю замінити людський, а ефективність автоматизації прийняття рішень визначається тим, наскільки саме використовуються сильні сторони особи, що приймає рішення. Саме для цього і запроваджується людино-машинна система прийняття рішень, розробляються методи, алгоритми, за допомогою яких забезпечувалося б ефективне співробітництво людей і комп'ютерного середовища під час підготовки та прийняття рішень [5].

3 огляду на викладене було доцільно створити певні критерії та методи, які б за допомогою грамотної організації перерозподілу судових справ за допомогою людського інтелекту, через автоматизовану систему зменшили б тотальну недовіру до суддів, знизили б їх завантаженість. Все це сприятиме забезпеченню доступності до правосуддя, що встановлено чинними законами.

Організація судового діловодства й документообігу сприяє забезпеченню доступності правосуддя для кожної особи в порядку, встановленому Конституцією України та законами; зумовлює головні впливові чинники та зв'язки в діловодних процесах. Виявлено, що діловодство в судах автоматизується за допомогою різних програм, серед яких «Діловодство суду», автоматизована система (АС) «Документообіг загальних судів» тощо. Однак нині в Україні працюють розрізнені інформаційні системи з автоматизації роботи в судах, які відповідають світовому рівню, але відсутні єдина наукова концепція і єдине інформаційно-технологічне середовище, що забезпечили б ефективну та скоординовану роботу судів 3 іншими державними органами влади.

Доведено, що система електронного судового документообігу є складною підсистемою інтегрованої інформаційної системи судочинства, функціонування якої пов'язане зі значною кількістю інформації, як внутрішньої (матеріали справи), так і зовнішньої (законодавство, економічні, соціальні фактори тощо). Комп'ютер має допомагати, а не повністю заміщати людину у здійсненні цієї функції. Адже оптимальні, ефективні з позицій інтересів суспільства рішення можливі лише у людино-машинній системі, коли машина надає альтернативні прораховані варіанти, а остаточний вибір найкращого має залишатися за людиною [5].

Деякі питання інформаційно-технічного й організаційно-правового характеру досліджуються в наукових працях таких учених, як І.Л. Бачило, О.О. Денисова, А.Ю. Каламайко, Н.І. Логінова, М.М. Пархоменко, В.О. Смірнова, О.Г. Трофименко, М.Я. Швець та інші [6].

Створення ефективної автоматизованої системи розподілу судових справ, що зорієнтована на реальну оптимізацію процесу документопотоків у судочинстві нашої країни, є найактуальнішим для досягнення цілей ефективного функціонування процесу правосуддя. Детермінування процесу організації розподілу судових справ є засобом започаткувати певну категоріальність.

Так, суди здебільшого використовують розподіл справ за такими категоріями: розподіл за спеціалізацією; розподіл випадковим чином в межах спеціалізації; розподіл почергово (натуральний ряд чисел, алфавіт тощо); пропорційний розподіл. Розподіл справ за спеціалізацією в деяких судах вважають ефективним, обгрунтовуючи тим, що це дає можливість удосконалювати знання, підвищувати кваліфікацію за певними галузями права. Інші судді вважають, що судді дискваліфікуються в інших галузях. На наш погляд, доцільним є розподіл за спеціалізаці$є ю$, але через певний проміжок часу, наприклад, коли певна категорія справи вже знаходилась у розгляді певного судді більше 20 разів. Також для ефективної роботи суду за можливості варто застосувати спеціалізацію для кожного судді з урахуванням певної категорії. Наприклад, Цивільні справи - спеціалізація (Окреме провадження) - кваліфікація (встановлення фактів).

Застосування принципу випадковості реалізує антикорупційний аспект, але раціональності, на наш погляд, у цьому не буде досягнуто, оскільки судді доведеться знову і знову під час прийняття кожної наступної (нової) справи різної спеціалізації та/або категорії до провадження наново досліджувати всі закони, підзаконні нормативно-правові акти, судову практику тощо. На цей процес витрачається неабиякий проміжок часу та зайві продуктивні сили. А як ми знаємо, інтелектуальний труд $є$ не менш виснажливим, ніж фізичний.

3 огляду на викладене за наявності автоматизованої системи розподілу судових справ треба враховувати вимоги законодавства щодо позачерговості розгляду справи та строків розгляду певної категорії, а також орієнтуватись на важливість певної ії категоріiі, що є обгрунтованим за раціонального розподілу серед штучного інтелекту через автоматизовану систему та за допомогою людського мислення. 


\section{ЛІТЕРАТУРА:}

1. Положення про автоматизовану систему документообігу суду: Рішення Ради суддів від 02.04.2015 p. № 25. URL: https://zakon.rada.gov.ua/rada/show/v0025414-15/print.

2. Інноваційні методи адміністрування в українських судах. Практичний досвід. Київ, 2010. 284 с.

3. Вдовіна О.О. Нормативно-правові засади впровадження автоматизованого судового документообігу. Бібліотекознавство. Документознавство. Інформологія. 2014. № 4. С. 29-32.

4. Конституція України від 28.06.1996 року № 254/96 ВР. Відомості Верховної Ради України. 1996. № 30. URL: https://zakon.rada.gov.ua/laws/main/254\%D0\%BA/96-\%D0\%B2\%D1\%80.

5. Саранюк В.І. До порядку автоматизованого документообігу у розподілі судових справ «Інформація і право». № 2(2). 2011. URL: http://ippi.org.ua/sites/default/files/11svirss.pdf.

6. Гетманцев М.О. Єдина судова інформаційно-телекомунікаційна система: реальність і виклики сьогодення. Підприємниuзтво, господарство і право. 2017. № 4. C.179-183. URL: http://nbuv.gov.ua/UJRN/Pgip_2017_4_38. 